\title{
Mollusks of THE Continental Margin of Northeast Brazil Collected DURING JOPS II-6.
}

\author{
DEUSINETE DE OLIVEIRA TENÓRIO ${ }^{(\mathbf{1})}$ \\ Geraldo SEMER Pomponet De OLIVEIRA ${ }^{(2)}$ \\ 1 - Oceanography Department, Federal University of \\ Pernambuco \\ 2 - Education Department, State of Bahia, Salvador
}

\begin{abstract}
Geological and biological studies on the recent Quaternary of the northeastern coast of Brazil were accomplished during the 2nd expedition of R.V. Victor Hensen, project JOPS II, leg 6. The biological studies were made based on the material dredged at 17 stations off Ceará and Pernambuco States $\left(04^{\circ} 05,03^{\prime} \mathrm{S}\right.$ to $\left.07^{\circ} 59,5^{\prime} \mathrm{S}\right)$, in depths from 20 to 330 meters, using dredges with a capacity of 80 liters of sediment. At some stations, a Van Veen dredge was used. Mollusks were present at 14 stations with 229 individuals that belonged to 66 species. Species associations were studied through cluster analysis (Jaccard index) using WPGMA linkage. Species were grouped mainly by sediment grain size. The gastropods formed 4 large groups at a $50 \%$ similarity level with subgroups formed with more than $75 \%$ similarity. Bivalves formed 2 groups with $50 \%$ and subgroups with larger similarity than 75\%. The highest specific diversity was found at station 14 . The area with the highest abundance was characterized by sand, mud and gravel. Highest species richness and abundance was found at depths between 20 and 40 meters.
\end{abstract}

\section{Key-words: Mollusks, Oceanographic surveys, Tropical South Atlantic Ocean.}

\section{RESUMO}

Pesquisas geológicas e biológicas sobre o Quaternário Recente da costa Nordeste do Brasil foram realizadas durante a $2^{a}$ expedição do Navio Oceanográfico Victor Hensen, projeto JOPPS II, $6^{a}$ pernada. As pesquisas biológicas foram feitas tendo como base o material dragado em 17 estações entre os estado de Ceará e Pernambuco (04 $05,03^{\prime} \mathrm{S}$ e $\left.07^{\circ} 59,5^{\prime} \mathrm{S}\right)$, em profundidades de 20 a 70 metros e 200 a 330 metros, sendo utilizadas dragas de arrasto com capacidade de 80 litros de sedimento e em algumas estações foi utilizada a draga de Van Veen. Os moluscos estiveram presentes em 14 estações com 66 espécies e 229 exemplares. As associações entre as espécies foram estudadas através da analise de cluster (índice de Jaccard) com método de ligação WPGMA, sendo formado agrupamentos de espécies relacionadas principalmente pela granulometria do sedimento. Os gastrópodes formaram 4 grandes grupos a um nível de 50\% de similaridade com subgrupos formados com mais de $75 \%$ de similaridade e os bivalves 2 grupos a $50 \%$ e subgrupos com similaridade maior que $75 \%$. O índice de diversidade específica mais alto foi apresentado na estação 14. O fundo mais povoado foi o constituído de areia, lama e cascalho e as profundidades entre 20 e 40 metros foram as melhores representadas por espécies e exemplares.

Palavras chave: Moluscos, Expedição Oceanográfica, Atlântico Sul. 


\section{INTRODUCTION}

During the Brazilian-German JOPS II Project - Leg 6, geological and biological studies were accomplished on the recent Quaternary at the coastal area of northeastern Brazil. Samples were taken between the states of Ceará and Pernambuco, in 1995, on board R.V. Victor Hensen.

The biological studies consisted of samples collected with dredges at 17 stations in the interior potion of the continental shelf (from 20 to 40 meters and 60 to 70), to the shelf slope (220 to 330 meters). Samples were taken between Fortaleza (Ceará State) and the outlet of the Mossoró river, the slope area between Natal (Rio Grande do Norte State) and Recife (Pernambuco State), and off the inlets of the rivers Jaguaribe, Açu, Mossoró, Potengí Mamanguape and Paraíba.

The continental margin of northeast Brazil has been studied, mainly in shelf areas. The mollusks of this area have been studied with the objective to determine the diversity of the species. Notable are the studies of Kempf \& Matthews (1967), Kempf (1970), Matthews \& Kempf (1970), Mello (1977), Barros (1994), and Tenório \& Oliveira (1996), among others.

The main objective of this work to contribute to the knowledge on the Living Resources of the Exclusive Economic Zone of Brazil.

\section{MATERIALS AND METHODS}

Benthos samples were collected during leg 6 on board R.V. Victor Hensen off the northeast Brazilian coast in an area from the mouth of the river Jaguaribe in Ceará State $\left(04^{\circ} 0503^{\prime} \mathrm{S}\right.$ and $\left.37^{\circ} 35^{\prime} 75^{\prime} \mathrm{W}\right)$ to Pernambuco State $\left(07^{\circ} 59^{\prime} 5^{\prime} \mathrm{S}\right.$ and $\left.34^{\circ} 14^{\prime} 5 \mathrm{~W}\right)$, at 17 stations between the depths of 20 and 330 meters, using dredges with a capacity of 80 liters. Some samples were collected with a Van Veen dredge.

At each station, salinity and temperature were measured, and the composition of the sediment was analysed.

The organisms were washed and sorted on board, preserved in $70 \%$ alcohol and later stored in the benthos section of the Oceanography Department of the Federal University of Pernambuco. Mollusks were identified and kept separately in the collection of the mentioned Department.

The stations were numbered from 1 to 17 . Stations number 2, 5 and 12 did not contain any representatives of the Phyllum Mollusca. table 1.

Data on depth, bottom type and geographical coordinates of the stations are represented in

Multivariate analysis based on the occurrence of the species, using the Jaccard index and WPGMA linkage (Weight Pair Group Mathematical-Arithmetic Average) (Rahlf \& Fischer, 1968). Cophenetic analysis was performed to verify the significance of the cluster dendrograms.

For the calculation of the index of specific diversity and evenness of each station, the Shannon index (1948) was used, as built in the ECOLOGICAL program.

The analysis of the sediment was made at the Geology Laboratory of the Federal University of Pernambuco.

\section{RESULTS}

Thirty-two families, 50 genera and 66 mollusk species were identified, belonging the classes Gastropoda and Bivalvia. The gastropods represented $70 \%$ of the identified species. The family Conidae was clearly representing the largest number of species.

Most of the stations presented a medium index of specific diversity, (>2.0) (Figure 1), the highest index (4.0) was found at station 14, where 20 species were collected, mostly bivalves. This 
station was 49 meters deep and showed a sand-gravel bottom (SG). The second largest diversity index belonged to station 13 (> 3), with 15 species, most of them constituted by gastropods. The granulometry of the sediment indicates a sandy bottom with a large gravel percentage, being therefore classified as gravel-sand (GA), and a depth of 20 meters. The highest diversities coincide with the presence of gravel at sandy bottoms. The lowest diversity occurred at station 10, with a depth of 330 meters and low temperatures at station 6 due to_calcareous bottom.

Table 1 - Data about the collection stations.

\begin{tabular}{c|c|c|c|l}
\hline STATION & $\begin{array}{c}\text { LATITUDE } \\
(\mathbf{S})\end{array}$ & $\begin{array}{c}\text { LONGITUDE } \\
(\mathbf{W})\end{array}$ & $\begin{array}{c}\text { DEPTH } \\
(\mathbf{M} .)\end{array}$ & \multicolumn{1}{|c}{ BoTTOM TYPES } \\
\hline 01 & $04^{\circ} 05,03^{\prime}$ & $37^{\circ} 35,75^{\prime}$ & 23 & Sand, Mud and Gravel /Halimeda (SMG) \\
\hline 03 & $03^{\circ} 56,55^{\prime}$ & $37^{\circ} 31,05^{\prime}$ & 220 & Sand - Gravel (SG) \\
\hline 04 & $04^{\circ} 34,65$ & $36^{\circ} 53,00^{\prime}$ & 70 & Gravel - Sandy (GS) \\
\hline 06 & $04^{\circ} 40,42^{\prime}$ & $36^{\circ} 37,89^{\prime}$ & 60 & Calcareous (C) \\
\hline 07 & $04^{\circ} 46,73^{\prime}$ & $36^{\circ} 39,72^{\prime}$ & 21 & Sand/Halimeda (S) \\
\hline 08 & $05^{\circ} 04^{\prime}$ & $35^{\circ} 17,99^{\prime}$ & 20 & Sand - Gravel (SG) \\
\hline 09 & $05^{\circ} 0^{\prime}$ & $35^{\circ} 03,42^{\prime}$ & 62 & Gravel - Sandy (GS) /Lithothamnium \\
\hline 10 & $05^{\circ} 45,59^{\prime}$ & $35^{\circ} 04^{\prime}$ & 330 & Sand, Mud and Gravel (SMG) \\
\hline 11 & $05^{\circ} 46^{\prime}$ & $35^{\circ} 03,65^{\prime}$ & 20 & Sand, Mud and Gravel (SMG) \\
\hline 13 & $06^{\circ} 18,62^{\prime}$ & $34^{\circ} 55,70^{\prime}$ & 20 & Gravel - Sandy (GS) /Lithothamnium \\
\hline 14 & $06^{\circ} 57,8^{\prime}$ & $34^{\circ} 34,6^{\prime}$ & 49 & Sand - Gravel (SG) \\
\hline 15 & $06^{\circ} 58,1^{\prime}$ & $34^{\circ} 43,1^{\prime}$ & 20 & Gravel - Sandy /Halimeda (CA) \\
\hline 16 & $07^{\circ} 43,7^{\prime}$ & $34^{\circ} 27,3^{\prime}$ & 70 & Sand, Mud and Gravel (SMG) \\
\hline 17 & $07^{\circ} 42,26^{\prime}$ & $34^{\circ} 43,50^{\prime}$ & 20 & Sand, Mud and Gravel (SMG) \\
\hline
\end{tabular}

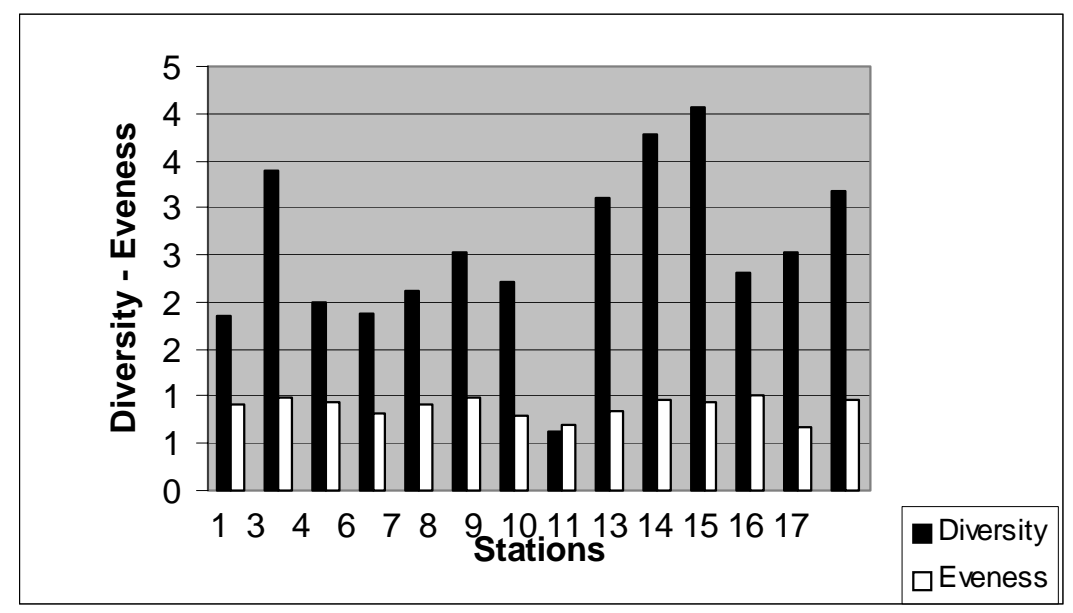

Figure 1 - Specific diversity and evenness at the studied stations. 
Evenness showed values between 0.6 and 1.0, indicating high evenness. This indicates a certain balance among species, the highest $(1,0)$ was at station 15 , with the same number of species and individuals.

The analysis of the sediment showed 5 bottom types. In agreement with the granulometry, these bottoms were classified as Sand, Gravel and Mud (SGM), Sand-Gravel (SG), Gravel-Sand (GS) and Calcareous (Ca). The sediments that were composed of Sand, Mud and Gravel, were the most densely populated. Sediments with large percentage of sand, and calcareous bottoms showed the lowest numbers of species and individuals (Figure 2).

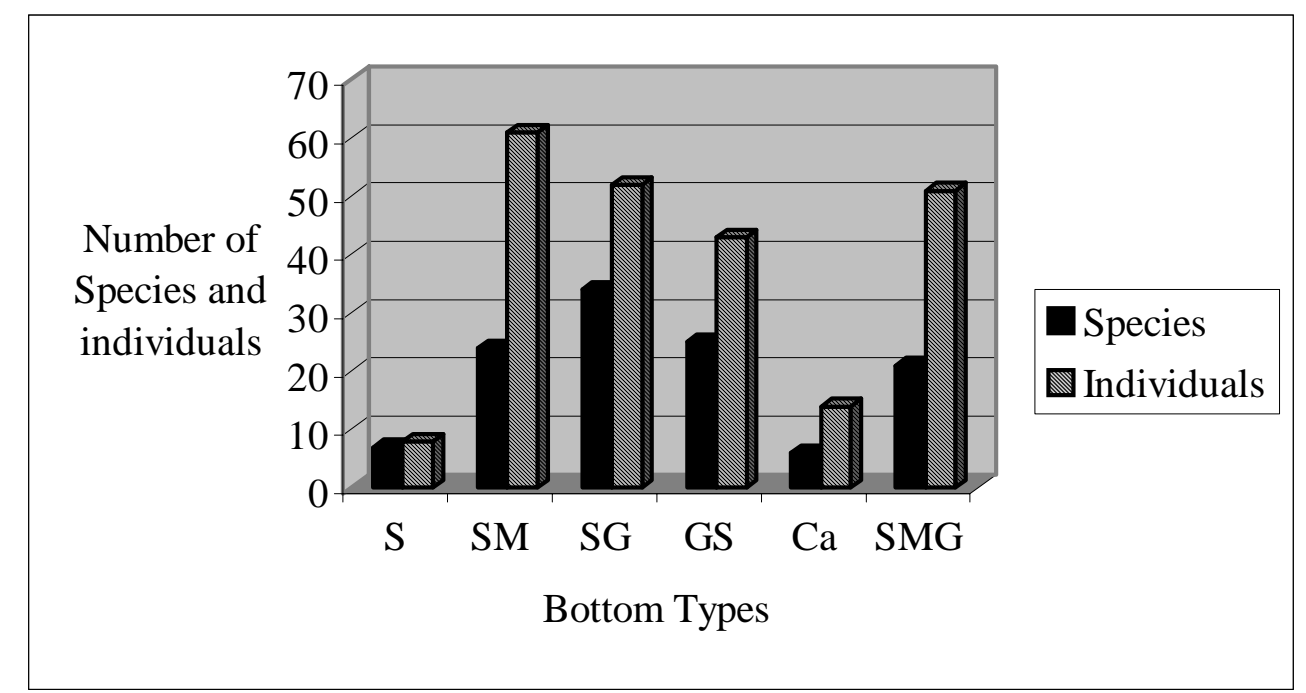

Figure 2 - Representation of the number of species and individuals on several bottom types. S = Sand, SMG = Sand, Mud and Gravel, SG= Sand-Gravel, GS = Gravel-Sandy $\mathrm{Ca}=$ Calcareous.

At 14 stations, the depths were 20, 21, 23, 49, 60, 62, 70, 220 and 330 meters (Table 1). At a depth of 20 meters the largest numbers of species and individuals were observed (Figure 3). 


\section{Species $\prec$ Individuals}

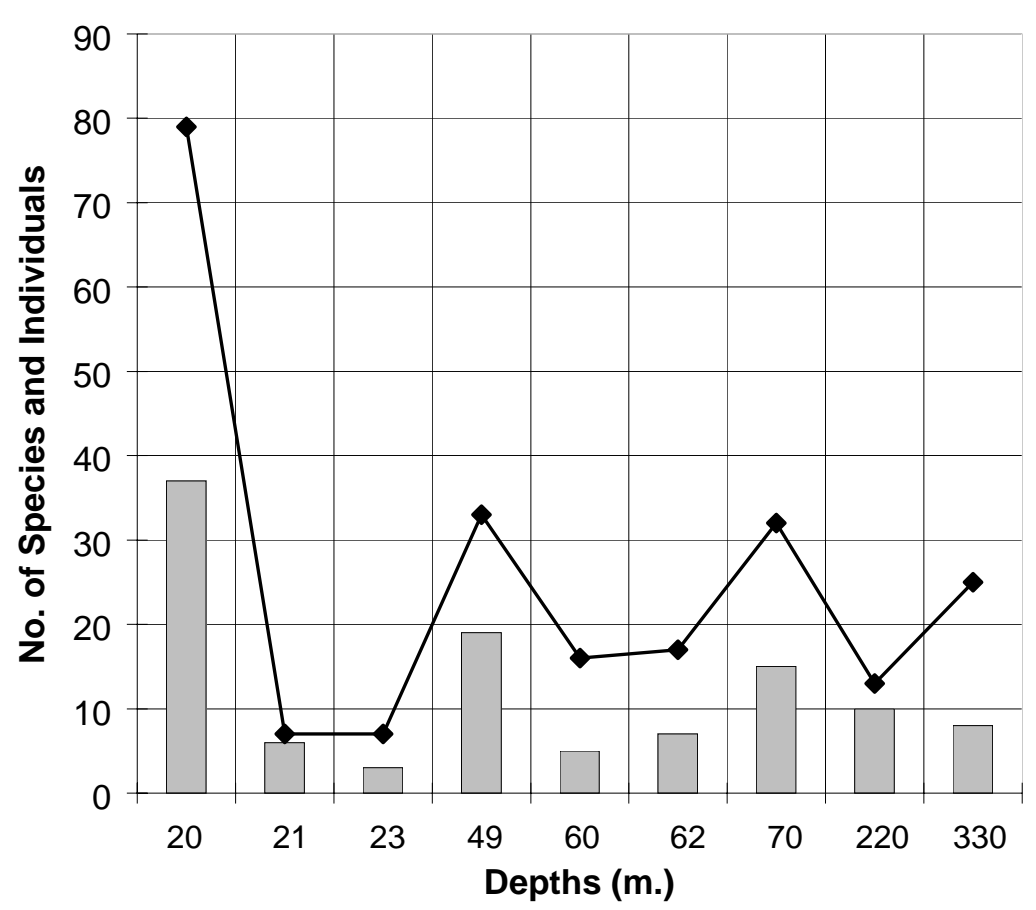

Figure 3 - Distribution of the number of species and individuals at different depths.

Stations that corresponded to this depth were found between the coast of Rio Grande do Norte and Pernambuco. Hydrological data of the area showed temperatures between $28,55^{\circ} \mathrm{C}$ and 29,51 ${ }^{\circ} \mathrm{C}$, and salinities between 36,74 ppm. and 37,04 ppm.

Cluster analysis of the gastropod species displayed 4 groups starting at $50 \%$ similarity (Figure 4). The first group was formed by 6 species, among them Turbo canaliculatus, Modulus modulus, Columbrarium sp and Tonna maculosa that were gathered and formed a subgroup with a similarity index of $75 \%$. These species occurred at stations where the predominant bottom was sand, mud and gravel, in depths between 20 and 49 meters. The second group was formed by 9 species, standing out the species Cypraea spurca and Cypraea cinera grouped with $80 \%$ similarity. These occurred at 5 stations, where the depths varied between 20 and 330 meters, thus showing a eurybathic distribution.

The third group was composed of 16 species that were distributed at stations with a very similar sand-gravel bottom type, standing out a subgroup constituted by the species Turritella exoleta and Polystira sp. 


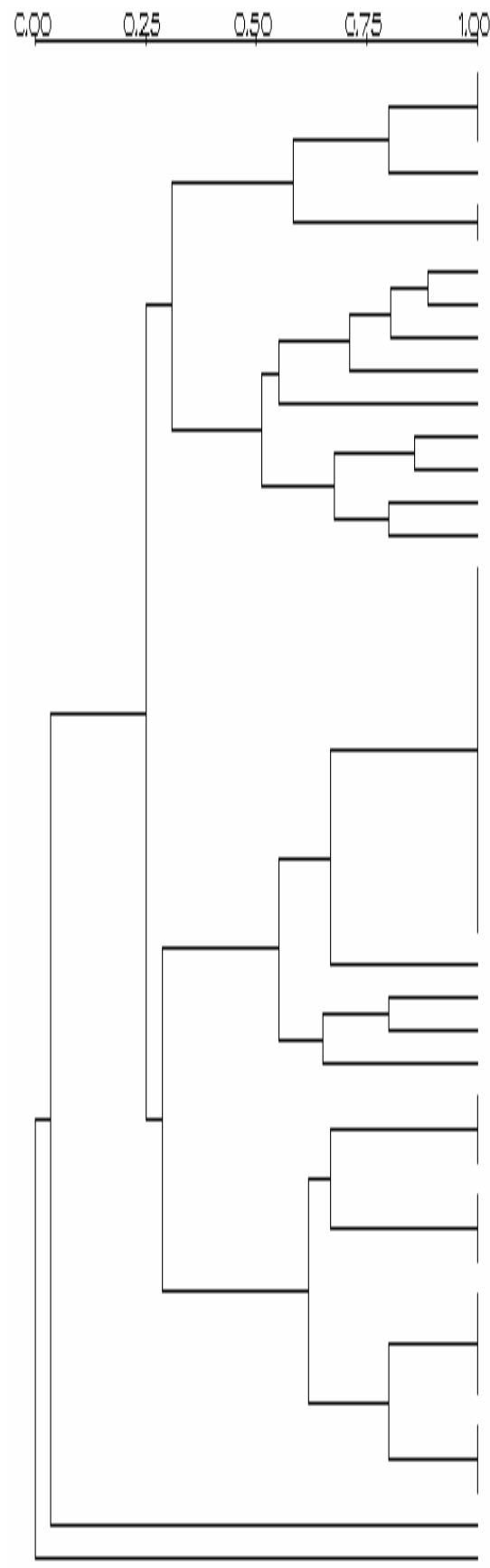

Turbo canaliculatus

Modulus modulus

Colubraria sp.

Tonna maculosa

Cassis tuberosa

Antillophos candei

Cypraea spurca

Cypraea cinera

Conus selenae

Conus sp.

Cymatium comptum

Trivia suffusa

Trachypollia turricula

Oliva circinata

Terebra protexta

Strombus gallus

Xenophora caribaea

Cypraea surinamensis

Cerithium eburneum

Phalium granulatum

Bursa corrugata

Conus jaspideus

Subcancilla candida

Opalia crenata

Colubraria obscura

Olivella nivea

Pleuroploca aurantiaca

Nassarius albus

Turritella exoleta

Polystira sp.

Columbella mercatoria

Polinices uberinos

Marginella cloveri

Pyrgospira ostrearum

Distorsio clathrata

Conus regius

Bursa rhodostoma thomae

Bursa grayana

Conus daucos

Mitra nodulosa

Phyllonotus pomum

Persicula sagittata

Volvarina sp.

Conus mundanus

Cerithium biminie

Figura 4 - Similarity among the gastropods species at different stations

The second cluster dendrogram (Figure 5), shows grouping of bivalves at different stations. At a similarity level of $50 \%$, there was a association into two great groups. The first group was represented by 7 species, distributed at similar depths and bottoms, two of them, Trachycardium 
magnum and Macoma pseudomera formed a subgroup with a similarity level of $75 \%$. These species occurred on sand-gravel and gravel bottoms, in depths between 20 and 70 meters, with the same number of individuals. This bottom type and depth is compatible with other published work on the ecology of these species, Rios (1995) mentions that T. muricatum lives on sandy bottoms and on calcareous algae in depths from 20 to 150 meters, and Tenório et al. (1986) affirm that $M$. pseudomera was distributed on bottoms of sand and mud between 9 and 72 meters depth.

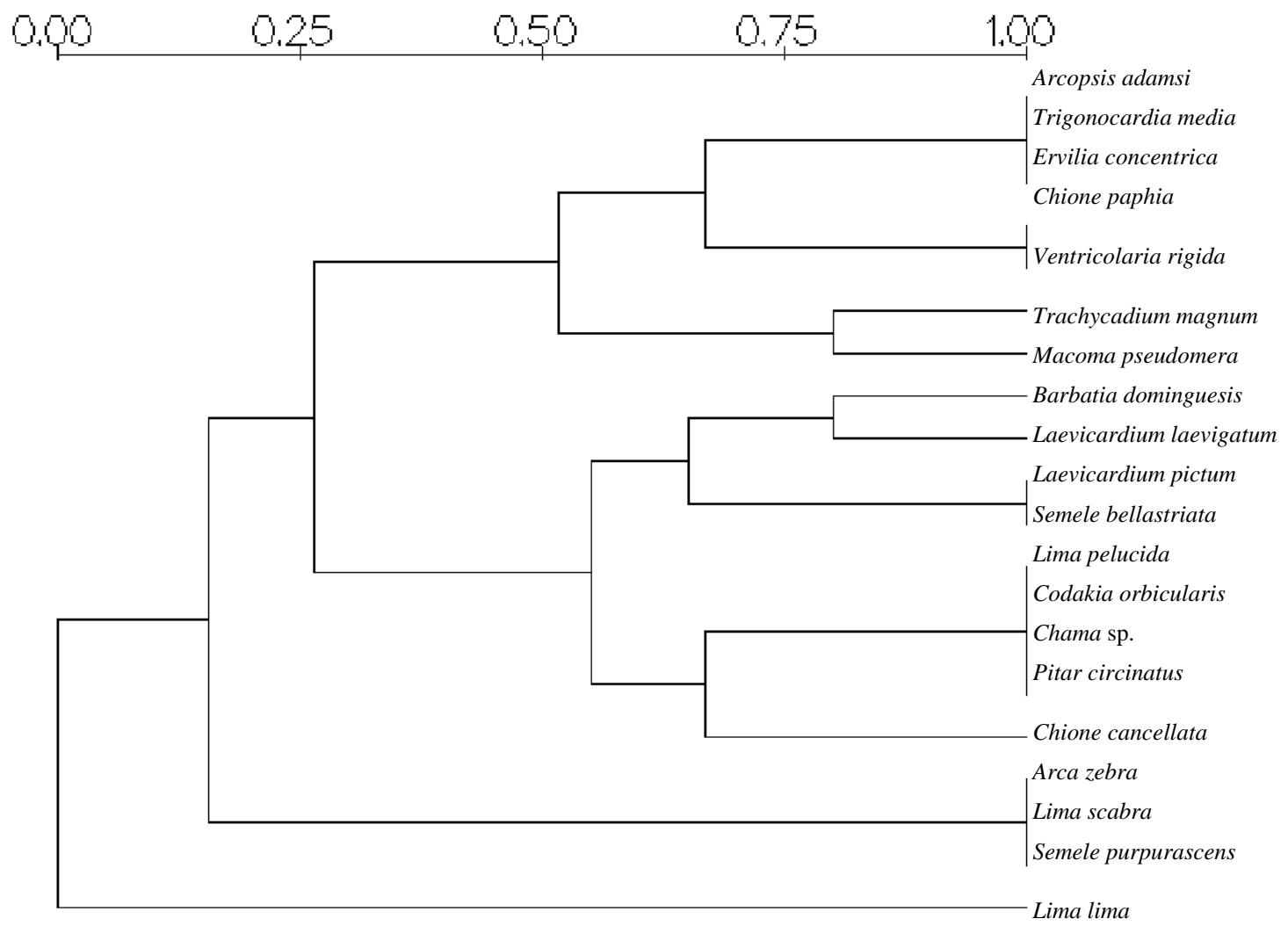

Figure 5. Similarity among the bivalve species at different stations.

The second grouping of bivalves is formed by 9 species. A subgroup formed with more than $75 \%$ similarity, was composed by Barbatia dominguensis and Laevicardium laevigatum, these species being more strongly associated with the frequency at stations and the sandy sediment. The species Arca zebra, Lima scabra and Semele purpurascens don't present likeness with other species due to sporadic occurrence at the stations sampled and Lima lima appears completely dissociated of the whole grouping, due to its presence at a station with calcareous bottom. No other bivalve species was present at this station.

\section{List OF THE FAMILIES AND SPECIES AT STATIONS.}

GASTROPODA Turbinidae Station 11(2) Modulidae Modulus modulus (Linnaeus, 1758) Station 11(10), 16(1) Strombidae Strombus gallus Linnaeus, 1758 Station 14(2) Xenophoridae Xenophora caribaea Petit, 1856 Station 3 (2) Cypraea surinamensis Perry, 1811 Station 3(1) Cypraea spurca acicularis Gmelin, 1791 Station 3 (2), 6(4), 9(1), 11(5), 13(3), 14(1), 16(1) Cyraea cinera Gmelin, 
1791 Station 6(8), 7(3), 9(8), 10(1), 11; Triviidae Trivia suffusa (Gray, 1832) Station 6(1), 7(1), 16(1)

Naticidae Naticidae Polinices uberinus (Orbigny, 1842) Station 13(1) Turritellidae Turritella exoleta (Linnaeus, 1758) Station 7(1), 8(1), 10(15), 11(5), 14(2) Cerithiidae Cerithium eburneum Bruguiére, 1792 Stationm 14(6) Cerithium biminiensis Pilsbry \& McGinty, 1948 Station 6(1); Tonnidae Tonna maculosa (Dillwyn, 1817) Station 3(1), 11(1), 14(1), 16(1); Cassidae Phalium granulatum (Born, 1778) Station 3(1); Cassis tuberosa (Linnaeus, 1758) Station 10(1); Ranellidae Cymatium comptum (A. Adams, 1855) Station 16(1); Distorsio clathrata (Lamarck, 1816) Station 3(2), 15(1); Bursidae Bursa rhodostoma thomae (Orbigny, 1842) Station 13(1),14(1) Bursa grayana (Dunker, 1868) Station 11(1), 13(2), 14(1); Bursa corrugata ponderosa (Reeve, 1844) Station 3(1) Epitonidae Opalia crenata (Linnaeus, 1758) Station 3(1) Muricidae Phyllonotus pomum ocolatus (Reeve, 1845) Station 10(1), 11(1), 13(1), 14(3); Trachypollia turricula (von Maltzan, 1884 Station 1(1), 13(2) Buccinidae Antillophos candei (Orbigny, 1842) Station 10(2); Columbellidae Columbella mercatoria (Linnaeus, 1758) Station 7(1),8(1) Nassariidae Nassarius albus (Say, 1826) Station 14(1), 16(1) Fasciolariidae Pleuroploca aurantiaca (Lamarck, 1816) Station 8(1) Colubraria obscura (Reeve, 1844) Station 14(1)4 Colubraria sp. Station 14(1),17(1); Olividae Oliva circinata Marrat, 1881 Station 1(2), 15(1), 17(1) Olivella watermani McGinty, 1940) Station 16(3), Olivella nivea (Gmelin, 1791) Station 3(1) Marginellidae; Marginella cloveri Rios Matthews, 1972) Station 9(1); Persicula sagittata (Hinds, 1844) STATION 11(2), 13(2); Volvarina sp Station 11(1), 13(1) Mitridae Mitra nodulosa (Gmelin, 1791) Station 10(1), 11(1), 13(1), 14(1) Subcancilla candida (Reeve, 1845) Station 13(1) Conidae Conus daucus Hwass, 1792 Station 10(2), 13(1), 14(1) Conus jaspideus Gmelin, 1797 Station 8(1) Conus regius Gmelin, 1791 Station 9(1), 13(1); Conus selenae van Mol Turch \& Kempf 1967 Station 9(1), 11(1), 13(1), 16(1) Conus mundanus Hwass, 1792 Station 4(2), 16(1) Conus sp Station 1(1), 11(1) Turridae Pyrgospira ostrearum (Stearns, 1872) Station 9(1) Polistira sp Station 3(1), 10(2); Terebridae Terebra protexta (Conrad, 1846) Station 7(1), 17(1) BIVALVIA Arcidae Arcopsis adamsi (Dall, 1886) Station 17(2);Barbatia dominguensis (Lamarck, 1819) Station 4(1), 14(2); Arca zebra (Swainson, 1843) Station 13(1) Limidae Lima pelucida (C.B.Adams, 1846) Station 14(1) 13(1) Lima scabra (Born, 1778) Station 4(1),9(4) Lima lima (Linnaeus, 1758) Station 6(2) Lucinidae Codakia orbicularis (Linnaeus, 1809) Station 3(1), 14(1); Chamidae Chama sp. Station 8(2) Cardiidae Trachycardium magnum (Linnaeus, 1758) Station 14(1), 16(1), 17(1); Trigonocardia media (Linnaeus, 1758) Station 16(1) Laevicardium laevigatum (Linné, 1758) Station 13(2), 17(3) Laevicardium pictum (Ravenel, 1861) Station 14(2), 16(16); Tellinidae Macoma pseudomera Dall \& Simpson, 1900 Station 1(3); Semelidae Semele bellastriata (Conrad, 1836) Station 140, 16 e 17; Semele purpurascens (Gmelin, 1797) Station 15(1); Ervilia concentrica (Holmes, 1860) Station 17(1); Veneridae Chione paphia (Linnaeus, 1767) Station 15(1), 17(2) Chione cancellata (Linnaeus, (1767) Station 14(2) Ventricolaria rigida (Dillwyn, 1817), Station 15(1), 17(1) Pitar circinatus (Born, 1778) Station (2).

\section{DISCUSSION}

The composition of the mollusk fauna in the study area indicates the presence of only two classes of mollusks, Gastropoda and Bivalvia with predominance of the gastropods.

Among the several factors that influenced the distribution of the mollusks, the composition of the sediment seems to be the most important. The stations that presented bottoms of sand, mud and gravel (SMG) and sand and gravel (SG) were the more densely populated and had a higher diversity index. The heterogeneity of the bottom with a larger percentage of thicker sediments seems to favor the mollusks. Fine sediments are more homogeneous, presenting a smaller number of exploitable niches, and therefore, a lower diversity (Fresi et al, 1983).

Tropical Oceanography, Recife, v. 29, n. 1, p. 19-29, 2001. 
The diversity was highest at station 14, where a bottom of sand and gravel was present and a depth of 49 meters. The lowest diversity values were observed at station 10 , the deepest with 330 meters with a temperature of $8,43^{\circ} \mathrm{C}$ and a salinity of $34,42 \mathrm{ppm}$. At this station, 8 gastropod species were dredged and bivalves were not present.

Cluster analysis of the species showed associations formed mainly due to grain size distribution of the sediment. Other factors also contributed, such as the depth and the frequency of the species. Cophenetic analysis of the associations of gastropod species presented a $r=0.77$ and $\mathrm{r}=0.95$ for bivalves, both values being significant.

The gastropods formed 4 groups of species with $50 \%$ similarity, with associated subgroups of more than $75 \%$ similarity. In the first group, 4 species were most strongly associated, Turbo canaliculatus, Modulus modulus, the most abundant, the individuals were dredged mostly in depths of 20 meters and all in a bottom composed of sand, mud and gravel. This species was mentioned by Rios (1995) on muddy bottoms in the intertidal zone, Columbrarium sp. and Tonna maculosa were dredged also on the same bottom. For Matthews \& Kempf (1970) this is a coastal species, quite common in the Northeast of Brazil, between the states of Ceará and Alagoas. The second grouping is constituted of 9 species, standing out the ones of the genus Cypraea >7.5. Among these, C. spurca and $C$. cinera were the most abundant, and are quite common in the Northeast of Brazil, Olive circinata, which is a carnivore of shallow waters (Rios 1995), dredged in 20 and 23 meters, and Terebra protexta that was collected in the same depth. Matthews et al (1975) mention this species between 23 and 60 meters in sandy parts of banks of the calcareous algae Rodophyceae Melobesiae, between Ceará and Alagoas. The third grouping of gastropod species is the most numerous, constituted by 16 species, 7 of them collected in 220 meters depth (Xenophora caribaea, Cypraea surinamensis, Phalium granulatum, Bursa corrugata, Opalia crenata, Olivella nivea and Polystira sp.). The last two species of this dendrogram are dissociated of the others, possibly for the sporadic occurrence and because one of them, Cerithium biminiensis, was present on calcareous bottom.

The class Bivalvia formed 3 groups with $50 \%$ similarity. The first group showed 7 species, mostly dredged on bottoms composed of sand, mud and gravel. In this group, two species were also associated by the depth distribution, at a level of $>75 \%$. These species are Trachycardium magnum, that occurred up to 70 meters, a species mentioned by Matthews \& Kempf (op. cit) in depths starting from 25 meters, and Macoma pseudomera, collected in 23 meters in bottoms of sand, mud and gravel, mentioned by Tenório et al. (1986) in depths of 9 and 72 meters in bottoms of sand, mud and calcareous algae. The second group was formed by 9 species, with an index $>50 \%$, where Laevicardium pictum was standing out for being the most abundant, occurring at 49 and 70 meters. Kempf (1970) stated that it is a species of the circalitoral of the North and Northeast of Brazil. The species Arca zebra, Lima scabra and Semele purpurascens didn't form groups due to their presence on gravel-sand bottoms, and the species Lima lima, is dissociated from the other groups due to its occurrence on calcareous bottom.

\section{ACKNOWLEDGEMENTS}

This study was supported by the Science Foundation of Pernambuco State (FACEPE).

\section{REFERENCES}

ABBOTT, R. T. American Seashells: the Marine Mollusca of the Atlantic and Pacific coastof North America. $2^{a}$ ed. New York: Van Nostrand Reinhold, 1974. 663 p. 24 pls. ABBOTT, R. T. The

Marine Mollusks of Grand Cayman Is. B. W. I Monogr. Acad. Nat. Sci Phil., 1958, 11:7-138,5 pl. 7 text fig. 
ABBOTT, R. T.\& DANCE, S. P. Compendium of Seashells. New York: E. P. Dutton, 1982. 411 p.

BARROS, J. C. Estudo dos Componentes Bióticos da margem Continental Brasileira. I. Micromoluscos dragados durante a comissão “Canopus”, entre 1965 e 1966. Boletim do Museu de Malacologia, Universidade Federal Rural de Pernambuco, Recife, v.2, p. 57-84, 1994.

CARDOSO, P. S. \& RIOS, E.C. Lista Preliminar de los Moluscos Marinos de Alagoas. Comunicaciones de la Sociedade Malacologica del Uruguay, Montevideu,2 (13): 117- 136, 1967.

COSTA, F. A. Anachis helenae nova especie de Columbellidae do litoral brasileiro Additional shells from coast of southern Brazil. The Nautilus, vol. IV, No.10, 109-113, 1893.

EINSENBERG, J. M. A Collectors Guide to Shells of the World. McGraw Hill Book Company, New York, 237 p. 158 plates, 1981.

FRESI, E.;GAMBE, M. C.; FOCARDI, S.; BARGAGLI, R.; BALDI, F. \& FALCIAL, I. Benthic community and sediment types: A strutural analisis. Marine Eccology 4 (2): 101-1983.

JACCARD, P. Nouvelles recherches sur la distribution florale. Bulletin de la Societé Vandoise de Science Naturelle. N. 44, p. 223-270, 1908.

KEMPF, M. \& MATTHEWS, H. R. Marine Molluscks from North and Northeast Brazil. Arquivo da Estação de Biologia Marinha da Universidade Federal do Ceará, 8 (1):87- 94, 1968.

KEMPF, M. Notes on benthic bionomy of the N-NE Brazilian shelf. Marine Biology, (5)3: 213224, 19701970.

MATTHEWS, H. R. \& KEMPF, M. Moluscos Marinhos do Norte e Nordeste do Brasil. II, Moluscos do Arquipélago de Fernando de Noronha. Arquivos de Ciências do Mar da Universidade federal do Ceará, 10 (1): 1-53, 1 fig., 1970.

MATTHEWS, H. R. \& RIOS, E. C. Primeira Contribuição ao Inventário dos Moluscos Marinhos do Nordeste Brasileiro. Arquivos de Biologia Marinha da Universidade Federal do Ceará. 7 (1): 153, 1967.

MATTHEWS, H. R. \& RIOS, E. C. Quarta Contribuição ao Inventário dos Moluscos Marinhos do Nordeste Brasileiro. Arquivos de Ciências do Mar da Universidade Federal do Ceará., 14 (1): 47-56, 1974.

MELLO, R. L. S. Prosobranchia (Mollusca-Gastropoda) Marinho de Pernambuco. Dissertação para concurso a Categoria de professor Assistente do Departamento de Pesca da Universidade Federal rural de Pernambuco. Recife, 1977.

MERLANO, J. M. O. \& HEGEDUS, M. P. Moluscos Del Caribe Colombiano - Um Catalogo ilustrado Colciencias - Fundacion Natura - invenar - p. 291, 1994.

MORRIS, P.A A Field Guide to Shells of the Atlantic and Gulf Coast and West Indies. Houghton Mifflin Company Boston, 330 p. 1974.

PETUCH, E. J. New Caribbean Molluscan Faunas. The Coastal Educatin \& Reserch Foundation, Inc. U.S. Charlottesville, Virginia, 154 p. 28 plates, 1987. 
PILSBRY, H. \& LOWE, H. N. West Mexican and Central Americana Mollusks Collected by H. N. LOWE. Proceedings the Academyof Natural Sciences of Philadelphia, v. LXXXIV 145 p., 1932.

RIOS, E. C. Seashells of Brazil. Fundação Cidade do Rio Grande, Museu Oceanográfico Prof. E. C. Rios, Universidade do Rio Grande. 2a . ed. 113 plates, 1994.

SHANNON, C. E. The Mathematical Theory of Comunication. Urbana University Press. 127 p, 1948.

STERRER, W. \& STERRER, C.S. Marine Fauna and Flora of Bermuda. A systematic Guide Identification of Marine Organisms. John Wiley \& Sons, New York, 1986, 724 p.

TENÓRIO, D. O, MELLO, R. L. S. \& SILVA, O. C.; O Gênero Macoma Leach, 1819 (Bivalvia Tellinidae) na Plataforma Continental Brasileira, Cad.Ômega Univ Fed. Rural PE. Sér. Ci. Aquát., Recife, n. 2, p :7 -39, 1986.

TINTEINOT, M. \& MORAIS, J.O. Geological and biological investigations of late Quaternary processes off Northeast Brazil. In: EKAU, W. \& KNOPPERS, B. Sedimentation processes and Productivity in the Continenetal Shelf Waters off East and Northeast Brazil. Joint Oceanographic Projects JOPS-II. Center for Tropical Marine Ecology. Bremen, p. 96-115, 1996.

TUCKER, R. A. \& DANCE, S. P. Compedium of Seashells. New York, 1974, 663 p.

WAY, K. R. The Encyclopedia of Shells. Facts on File, New York, 1991, 288p. 1200 fig.

WARMKE, G. L. \& ABBOTT, R. T. Caribbean Seashells. Pennsylvania Livingston Publ. 1961, 346p. 
